\title{
PENGARUH PERSIAPAN DAN KONDISI LINGKUNGAN TERHADAP FISIK DAN PSIKIS MAHASISWA DALAM PEMBELAJARAN ONLINE DI RUMAH AJA
}

THE INFLUENCE OF PREPARATION AND ENVIRONMENTAL CONDITIONS ON THE

PHYSICAL AND PSYCHIC OF STUDENTS IN ONLINE LEARNING AT HOME ONLY

\section{Putri Yanti}

Program Studi Psikologi, Fakultas kedokteran, Universitas Lambung Mangkurat

Jl. A. Yani km 36 Banjarbaru Kalimantan Selatan, 70714, Indonesia

Email:2010914120006@mhs.ulm.ac.id

No. Handphone : 081285937081

\begin{abstract}
ABSTRAK
Pandemi Covid-19 mulai menyebar di Indonesia sejak bulan Maret yang lalu. Di mana, Wuhan merupakan salah satu faktor utama penyebab munculnya virus ini. Semenjak virus ini menyebar ke berbagai belahan dunia, Indonesia termasuk salah satu negaranya. Sejak Maret yang lalu, aktifitas di Indonesia mulai dikurangi khususnya untuk menempuh pendidikan. Sehingga seluruh pelajar, khususnya mahasiswa harus melakukan pembelajaran via online di rumah aja. Pembelajaran ketika di rumah aja sangat erat kaitannya dengan kondisi fisik dan psikis mahasiswa yang dipengaruhi oleh persiapan mahasiswa dalam pembelajaran dan kondisi lingkungannya.
\end{abstract}

Kata-Kata Kunci: pembelajaran online, di rumah aja, pandemi Covid-19, fisik dan psikis, kondisi lingkungan

\begin{abstract}
The Covid-19 pandemic began to spread in Indonesia since last March. Where, Wuhan is one of the main factors causing the emergence of this virus. Since this virus spread to various parts of the world, Indonesia is one of the countries. Since last March, activities in Indonesia began to be reduced, especially for education. So that all students, especially students, have to do online learning at home. Learning at home is closely related to the physical and psychological conditions of students which are influenced by students' preparation for learning and environmental conditions.
\end{abstract}


Keywords: online learning, at home, the Covid-19 pandemic, physical and psychological, environmental conditions

\section{PENDAHULUAN}

Putri, C. P., Mayangsari, M. D., \& Rusli, R. (2020) menerangkan bahwa perguruan tinggi merupakan suatu tempat untuk mengasah dan mengembangkan kemampuan individu dan mempersiapkan diri untuk menjadi tenaga profesional yang akan mengarahkan pada sumber daya manusia yang berkualitas dan berkompeten dalam bidang masing-masing. Ada banyak siswa yang ingin menjadi mahasiswa demi melanjutkan dunia pembelajarannya ke jenjang yang lebih tinggi.

Tidak disangka di tahun 2020 pada bulan Maret tadi, pandemi Covid-19 menyerang ke bagian belahan dunia. Yang menyebabkan seluruh mahasiswa melakukan pembelajaran perkuliahan dengan online, khususnya di Indonesia. Besar harapan dari mahasiswa dalam pembelajaran secara offline, namun semua terkendala akibat virus ini.

Ketika melakukan pembelajaran online di rumah aja, sangat dibutuhkan persiapan diri yang matang dan kondisi lingkungan yang memadai serta mendukung. Mahasiswa sangat memperhatikan IP dan IPK nya dengan mengorbankan kesehatan fisik dan psikis. Putri, C. P., Mayangsari, M. D., \& Rusli, R. (2020) menyebutkan bahwa IPK merupakan suatu hal yang sangat penting bagi mahasiswa, yang mana nilai IPK sangat berpengaruh dalam kehidupan akademik pada masa studi, beasiswa, serta untuk melamar pekerjaan di masa depan. Dimata mahasiswa IPK tinggi merupakan penunjang kesuksesan mereka. Lantas, ada banyak mahasiswa yang stress akibat nilai IPK nya rendah dikarenakan terkejut dengan pembelajaran via online, sehingga menyebabkan terganggunya kesehatan fisik dan psikis mahasiswa.

\section{METODE PENELITIAN}

Penelitian dan penulisan ini merupakan penelitian yang menggunakan kajian literatur yang artinya sama dengan metode studi pustaka dan berdasarkan apa yang penulis rasakan serta jalani. Metode ini menggunakan beberapa jurnal yang telah diterbitkan dalam media internet dan beberapa pikiran yang terlintas dan dirasakan oleh penulis. Dalam melakukan kajian ini, penulis memperbanyak informasi, mencari hubungan ke berbagai sumber, membandingkan, memikirkan, 
merasakan dan menemukan hasil atas dasar data sebenarnya.

\section{HASIL DAN PEMBAHASAN}

Kondisi fisik dan psikis mahasiswa dipengaruhi oleh persiapan diri dan kondisi lingkungannya yang mana sekarang berada dalam pandemi Covid-19. Mahasiswa seharusnya mampu untuk mengelola dan menjaga kondisi fisik dan psikis nya agar tetap stabil, sehingga proses pembelajaran berjalan dengan lancar.

Penulis terlebih dahulu menyajikan pemaparan dan penjelasan tentang pandemi Covid-19, pembelajaran online, dan kondisi lingkungan yang berhubungan dengan mahasiswa. Penulis juga memaparkan apa saja faktor penentu yang mempengaruhi kondisi fisik dan psikis mahasiswa selama pembelajaran online di rumah saja.

Selain itu, dalam tulisan ini penulis juga memaparkan, menuliskan dan menyampaikan kalimat dari penulis sendiri, baik itu berdasar pengalaman maupun pikiran dan perasaan penulis. Seperti yang dikatakan oleh Ersis Writing Theory (EWT) yaitu, "Tulislah apa yang ada dipikiran bukan apa yang akan ditulis."

\section{Media dalam Pembelajaran}

Media merupakan suatu alat atau sarana yang dapat digunakan untuk penyampaian suatu pesan. Media pembelajaran merupakan alat atau sarana yang digunakan dalam proses pembelajaran, seperti teknologi. Media dalam pembelajaran sangat dibutuhkan oleh seluruh mahasiswa dalam perkuliahan. Dengan adanya media, sangat membantu dalam proses pembelajaran, khususnya dalam mencari informasi dan bahan bacaan. Oleh karena itu, mahasiswa harus mempersiapkan media yang akan digunakan untuk keberlangsungan pembelajaran via online.

Syaharuddin, $\quad$ S. (2020) menyampaikan bahwa sangat dibutuhkan dalam pengembangan pembelajaran melalui bermacam metode dan media dalam mengajar dan untuk proses belajar di kelas lebih menarik agar hasil belajar mahasiswa semakin lebih baik. Pengembangan ini ditujukan untuk para tenaga pengajar kemudian mahasiswa juga dituntut untuk mampu menguasai media utnuk pembelajaran. Salah satunya yaitu kemampuan mahasiswa dalam memahami dan menguasai penggunaan teknologi.

Permatasari, M. A. (2019) menjelaskan bahwa perkembangan ilmu pengetahuan dan teknologi sangat berpengaruh dalam proses belajar mengajar. Dalam proses belajar, 
khususnya dalam kondisi pandemi seperti sekarang. Mahasiswa harus mampu menguasai dalam penggunaan teknologi. Dengan kemampuan tersebut, membantu mahasiswa dalam proses pembelajaran. Contohnya seperti media zoom, e-learning, dan pembuatan power point. Pembelajaran melalui zoom terkadang membosankan apabila tidak dibuat semenarik mungkin dalam proses belajar mengajar. Sehingga dalam pembelajaran melalui zoom, sering menggunakan power point untuk penjelasan materi.

Dari hasil penelitian Kusuma, Buwono, \& Basri (dalam Permatasari, M. A. 2019:63) menunjukkan bahwa proses pembelajaran lebih efektif ketika menggunakan media power point dibandingkan dengan metode sederhana untuk mengingkatkan hasil kemampuan belajar. Dengan ini, mahasiswa juga senang dengan adanya pembelajaran menggunakan power point. Selain indah dilihat, power point juga sebagai penunjang mahasiswa dalam mengenal dan mengingat inti dari apa yang dipelajari.

Dalam pembelajaran melalui elearning, ada banyak mahasiswa khususnya mahasiswa baru masih sangat kurang dalam memahami penggunaan elearning. Hal ini sering membuat mahasiswa merasa cemas dan mudah kesal dalam pembelajaran menggunakan e- learning, sehingga mengganggu kesehatan psikis mahasiswa, seperti mahasiswa mudah kesal ketika tidak bisa mengaplikasikannya. Mengapa demikian, karena gaptek nya mahasiswa dalam teknologi canggih seperti e-learning, membuat mahasiswa bingung dalam bagaimana melihat materi dan kapan presensi diadakan, serta kebingungan dalam hal diskusi ketika dalam forum diskusi melalui e-learning. Namun disamping itu mahasiswa cenderung lebih senang belajar menggunakan e-learnign dibandingkan zoom dan power point. Karena, dengan melalui e-learning saja mahasiswa lebih bisa bersantai dan sambil rebahan ketika melakukan diskusi, serta sambil memenuhi kebutuhan perutnya. Sehingga, kondisi fisik dan psikisnya tidak terganggu. Namun, sebagian mahasiswa lebih menyukai pembelajaran melalui via zoom dan tampilan power point dibandingkan e-learning. Karena, membuat belajar dengan lebih mudah dipahami serta dapat bertanya langsung pada dosen.. Sehingga, pengaruh kondisi lingkungan pandemi seperti sekarang menyebabkan mahasiswa lebih konsentrasi dalam pembelajaran ketika menggunakan media power point. Namun, lebih bersantai dan rileks ketika menggunakan e-learning.

\section{Koneksi Internet Daerah Tempat Tinggal}


Koneksi adalah hubungan dalam proses suatu menghubungkan yang dapat memudahkan urusan-urusan atau kegiatan. Koneksi internet merupakan sistem jaringan komputer untuk memudahkan dalam interaksi antar jarak jauh. Pastinya, setiap manusia di zaman sekarang tidak luput dari apa yang namanya koneksi internet, khususnya mahasiswa. Koneksi internet bisa didapatkan melalui kuota ataupun indihome (wi-fi).

Mahasiswa yang biasanya belajar dibangku perkuliahan, kini harus pulang ke daerah tempat tinggal masing-masing dan belajar di bangku rumah yang mungkin dianggap nyaman bisa, dianggap tidak nyaman pun juga bisa. Seluruh mahasiswa shock dengan kondisi pembelajaran via online. Karena mereka harus menyediakan device atau media, koneksi internet yang stabil, kuota yang cukup untuk kelancaran pembelajaran demi mendapatkan ilmu.

Dalam pembelajaran melalui online, pembelajaran sering dilakukan melalui via zoom dan e-learning. Untuk mengakses hal tersebut sangat dibutuhkan koneksi internet yang stabil. Namun, masalahnya di setiap daerah tempat tinggal itu tidak semua koneksi internet nya stabil, tidak semua mahasiswa juga mempunyai kecukupan ekonomi untuk selalu membeli kuota dan memasang wi-fi di rumah. Abbas, E. W., \& Erlyani, N. (2020) menyatakan bahwa bukan hanya persoalan koneksi internet saja yang menjadi penghalang dalam pembelajaran, namun keperluan kuota juga membuat perekonomian dan pengeluaran terkuras. Apalagi ketika cuaca tidak mendukung, seperti musim hujan, koneksi internet sangatlah buruk dan tidak bisa diharapkan. Dari persoalan ini, hampir seluruh mahasiswa merasa tertekan dalam pengelolaan agar koneksi internet stabil. Sehingga, kadang hal tersebut membuat mahasiswa menangis karena bingung bagaimana memberitahu dosen ketika jaringannya benar-benar dalam keadaan darurat. Terlebih dalam ulangan atau pengumpulan tugas, hal tersebut sangatlah mengganggu dalam proses penguatan psikis mahasiswa.

\section{Bencana Banjir Melanda Pada Musim Penghujan}

Undamg-Undang Nomor 24 tahun 2007 (dalam Mayangsari, M. D., Akbar, S. N., \& Rachmah, D. N. (2016) Tentang Penanggulangan Bencana, memiliki pengertian yaitu serangkaian peristiwa yang mengancam dan mengganggu kehidupan dan penghidupan masyarakat yang disebabkan oleh faktor alam dan atau non alam maupun faktor manusia, kerusakan lingkungan, kerugian harta benda dan dampak psikologis. Banjir merupakan keadaan dimana air yang 
meluap hingga memasuki area daratan. Banjir sangat sering ditemukan dan sangat sering pula terjadi. Tidak hanya di Indonesia, di luar negeri pula sering terjadi banjir.

Ketika melakukan pembelajaran via online, mahasiswa cenderung merasa bersantai dan lumayan merasakan kenikmatan, karena dapat dengan santai ketika belajar. Namun, disaat bencana seperti banjir melanda, maka kenikmatan dalam kata santai tersebut langsung hilang. Karena, mahasiswa langsung panik dengan air yang tiba-tiba naik dan memenuhi area rumah. Kondisi rumah dalam pembelajaran yang seharusnya nyaman dan tenang yang dapat membuat santai dan rileks tiba-tiba sirna dengan datangnya banjir. Keadaan banjir ini sangatlah membuat resah mahasiswa, karena mahasiswa kebingungan bagaimana dan dimana mereka harus berkuliah serta menetap. Sehingga, dengan terjadinya banjir membuat makan tidak teratur, pola hidup yang tiba-tiba berubah, koneksi internet juga sulit di akses, serta keaktifan dalam penugasan pun kurang. Karena, dalam penugasan terkadang mahasiswa di suruh mengumpulkan tugas ataupun hasil jawaban ulangannya dengan format file words atau dokumen maupun pdf. Namun, dengan dilandanya banjir, membuat mahasiswa tidak tahu harus berbuat apa.
Yang sehingga membuat mahasiswa telat dalam pengumpulan tugas ataupun tidak dapat mengerjakan sama sekali tugas yang diberikan dan meminta waktu untuk di diundur tanggal pengumpulannya. Dengan terkait hal pengumpulan tugas yang tidak dapat ditoleransi dosen ketika terlambat mengumpul, membuat mahasiswa selalu teringat akan kesalahan tersebut. Sehingga dapat membuat mahasiswa merasa menyesal dan depresi.

Dwi Mayangsari, M., Nur Rachmah, D., \& Rusli, R. (2020, June) menyatakan bahwa siswa atau mahasiswa yang berada di daerah rawan terkena bencana banjir supaya tidak mengalami ketertinggalan dan penurunan prestasi akademik agar tidak terganggu kondisi secara psikis membutuhkan daya juang yang sangat tinggi untuk mengatasi masalah dan hambatan risiko bencana secara baik yaitu dengan istilah Adversity Quotient (AQ). Dengan hal ini, mahasiswa dituntut untuk memiliki kemampuan AQ tersebut supaya mampu secara perlahan menjalani pembelajaran via online dengan sehat.

\section{Harmonisasi Lingkungan Sekitar Rumah}

Harmonisasi merupakan suatu bentuk upaya untuk mengatasi suatu batasan perbedaan atau upaya untuk mencari suatu keselarasan. Harmonisasi 
tidak luput dalam kehidupan manusia. Dengan adanya harmonisasi, manusia dapat hidup dengan rukun, damai, aman, dan nyaman. Harmonisasi lingkungan sekitar rumah merupakan salah satu faktor pendukung kelancaran pembelajaran mahasiswa ketika berkuliah di rumah saja.

Mahasiswa memerlukan kondisi lingkungan di sekitar rumah yang nyaman demi lancarnya kegiatan pembelajaran. Namun, disini penulis ingin menceritakan bagaimana harmonisasi lingkungan disekitar rumahnya pada saat penulis melaksanakan kegiatan pembelajaran online. Rusli, R. (2018, October) menjelaskan bahwa seperti yang kita ketahui, narkotika dan obat-obatan terlarang merupakan suatu hal yang sangat tidak baik dan sangat meresahkan masyarakat. Di tempat lingkungan rumah penulis, terdapat seorang laki-laki yang memiliki kebiasaan buruk yaitu menggunakan narkotika. Lelaki tersebut sering meresahkan warga sekitar, karena ketika dia menggunakan narkotika dia sering mengamuk. Sehingga dalam pembelajaran perkuliahan penulis, sering terganggu dan sering tidak konsentrasi karena ulah si laki-laki tersebut. Yang terkadang membuat penulis kesal dan menangis karena ketakunan dengan ulah laki-laki tersebut. Oleh karena itu, keadaan harmonisasi lingkungan sekitar juga merupakan faktor demi kelancaran pembelajaran mahasiswa di rumah saja.

\section{Keterjaminan Kesehatan Pola Hidup}

Dalam pembelajaran online di rumah aja, pola hidup mahasiswa sangat terjamin. Mahasiswa lebih mudah mengatur pola hidupnya ketikah berada di rumah dibandingkan dengan menjadi anak rantau. Selain waktu istirahat sangat banyak, pola makan mahasiswa pun lebih terjaga dan teratur dalam makan di kesehariannya. Karena kondisi pandemi seperti ini, seluruh mahasiswa dipersilahkan untuk kembali ke daerah tempat tinggal masing-masing dan berada di rumah. Dalam keterjaminan pola hidup, khususnya pola makan yang mana ada orang tua atau seorang ibu yang memperhatikan pola makan dan gizi seimbang untuk anaknya. Sehingga, dengan kondisi pandemi seperti ini, mahasiswa lebih memilih untuk pulang ke daerah tempat tinggal masing-masing dibandingkan menetap di kost.

Ketika berada di rumah, dekat dengan keluarga mahasiswa lebih mood dan banyak makan. Karena, makanan orang tua merupakan makanan paling enak dan tidak ada dua nya. Terlibat dalam pembelajaran perkuliahan, mahasiswa yang sekarang menjalani masa online, 
mereka lebih sering sarapan pagi dibandingkan ketikan kuliah offline.

Shinta (dalam Mattiro, S. 2019:9) menjelaskan bahwa sarapan pagi sangat penting dalam penunjang kebutuhan fisik, namun tidak hanya fisik saja, tetapi juga sangat berpengaruh dalam proses pembelajaran seorang anak. Selain fisik, psikis juga dipengaruhi oleh pola hidup, khususnya pola makan. Karena, dengan sarapan pagi, upaya untuk belajar sangat terasa mood nya. Gizinet (dalam Hartoyo, E., Sholihah, Q., Fauzia, R., \& Rachmah, D. N. 2015) menyatakan bahwa sarapan pagi dapat mempertahankan daya tahan tubuh saat berkegiatan, khususnya mahasiswa dalam pembelajaran perkuliahan, untuk memelihara kebugaran jasmani atau ketahanan fisik, membantu konsentrasi pikiran untuk belajar dan memudahkan dalam menyerap pembelajaran . Kemampuan anak khususnya mahasiswa dalam belajar dan mengingat serta memproses suatu pembelajaran, tentunya sangat membutuhkan energi sebagai penunjang semangatnya. Sehingga, pengaruh kondisi lingkungan dalam lingkup keluarga untuk memenuhi kebutuhan energi mahasiswa sangat berpengaruh dalam proses pembelajaran ketika dilaksanakan di rumah saja.

\section{KESIMPULAN}

Pandemi Covid-19 mengharuskan mahasiswa untuk melakukan kegiatan pembelajaran secara daring atau online. Yang mana mahasiswa harus pulang dan kembali ke daerah asal tempat tinggal. Hal ini berdampak pada kondisi fisik dan psikis mahasiswa dalam proses pembelajaran via online baik itu dampat positif dan dampatk negatif yang dipengaruhi oleh persiapan diri mahasiswa dan kondisi lingkungannya. Faktor penentu dampak pada kondisi fisik dan psikis mahasiswa melalui pembelajaran secara online yaitu persiapan diri mahasiswa dalam media pembelajaran, koneksi internet di daerah tempat tinggal, bencana banjir pada musim penghujan, harmonisasi lingkungan sekitar dan keterjaminan pola hidup mahasiswa ketika di rumah aja.

\section{DAFTAR PUSTAKA}

Abbas, E. W. (2020). Menulis Mudah, Menulis Ala Ersis Writing Theory.

Abbas, E. W., \& Erlyani, N. (2020). Menulis di Kala Badai Covid-19.

Dwi Mayangsari, M., Nur Rachmah, D., \& Rusli, R. (2020, June). Pengaruh pelatihan tanggap bencana banjir terhadap kecerdasan adversitas siswa dalam menghadapi banjir. Prosiding seminar nasional" Perkembangan penelitian 
penyakit tropis berbasis lahan basah dan kearifan lokal kalimantan selatan".

Hartoyo, E., Sholihah, Q., Fauzia, R., \& Rachmah, D. N. (2015). Sarapan Pagi \& Produktivitas. Universitas Brawijaya Press.

Mattiro, S. (2019). PENGETAHUAN

LOKAL IBU TENTANG PENTINGNYA GIZI DAN SARAPAN PAGI BAGI ANAK. PADARINGAN (Jurnal Pendidikan Sosiologi Antropologi), 1(1), $1-11$.

Mayangsari, M. D., Akbar, S. N., \& Rachmah, D. N. (2016). Upaya Kesiapsiagaan Masyarakat Pinggiran Sungai dalam Menghadapi Bencana Banjir Air Pasang. Jurnal Ecopsy, 2(1).

Permatasari, M. A. (2019). KEMAMPUAN MAHASISWA DALAM MENGGUNAKAN MEDIA PEMBELAJARAN. Vidya Karya, 34(1), 60-69.

Putri, C. P., Mayangsari, M. D., \& Rusli, R. (2020). PENGARUH STRES AKADEMIK TERHADAP ACADEMIC HELP SEEKING PADA MAHASISWA PSIKOLOGI UNLAM DENGAN INDEKS PRESTASI KUMULATIF RENDAH. Kognisia prodi Psikologi FK ULM, 1(2), 28-37.
Rusli, R. (2018, October). Psikoedukasi parenting skill dalam pendampingan pada anak dan remaja korban penyalahgunaan narkotika dan obat-obatan terlarang di Banjarmasin. In PROSIDING SEMINAR NASIONAL LINGKUNGAN LAHAN BASAH (Vol. 3, No. 1).

Syaharuddin,

S. (2020). PEMBELAJARAN MASA PANDEMI: DARI KONVENSIONAL KE DARING. PEMBELAJARAN MASA PANDEMI: DARI KONVENSIONAL KE DARING. 